
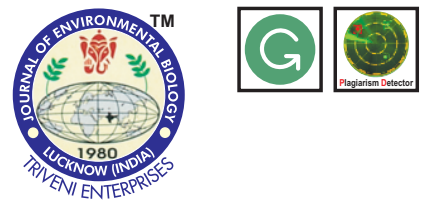

\title{
Bird diversity and conservation status in Isparta province (Turkey)
}

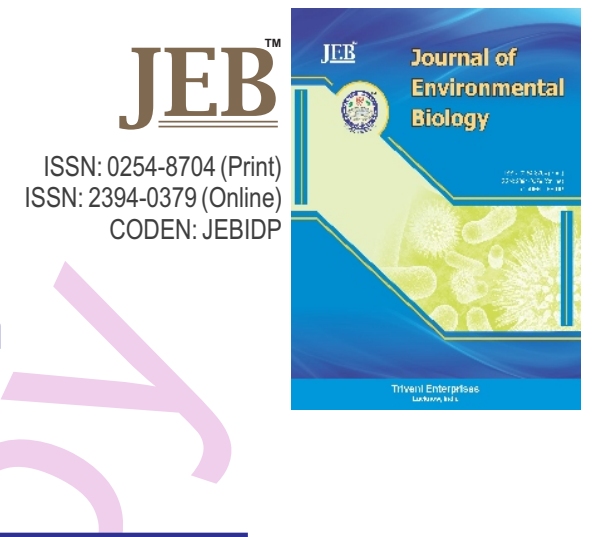

\author{
Authors Info \\ Y. Öztürk \\ Department of Forestry, Golhisar \\ Vocational School of Higher \\ Education, Mehmet Akif Ersoy \\ University, Gölhisar, Burdur, 15400, \\ Turkey
}

*Corresponding Author Email : yyaseminozturk@gmail.com

\section{Key words Bird diversity, Biodiversity, Conservation status, Isparta, Ornithofauna}

$$
\begin{aligned}
& \text { Publication Info } \\
& \text { Paper received : } 30.08 .2016 \\
& \text { Revised received : } 20.06 .2017 \\
& \text { Accepted : } 28.06 .2017
\end{aligned}
$$

\begin{abstract}
Aim : With its wetland areas, forests, high mountains and other habitat varieties, Isparta Province hosts many bird species. Furthermore, it provides birds with the opportunity of relaxation, breeding and accommodation in both the migration season and the rest of the period in a year due to its higly favourable geographical position and wetland areas. For this reason, the migration route of Northwest-South, which a part of the research area of this study is located, has great importance.
\end{abstract}

Abstract

Methodology : The species were determined by Line transect and Point counts method. Besides direct sighting and identification, the observations were made using some signs and traces belonging to birds such as footprints, faeces, voices, shape of wings and feathers.

Results : As a result of the field surveys performed during four different seasons (Winter-Spring-SummerAutumn), total 60.120 individuals and 266 bird species were determined. The research carried out during the period between 2013 and 2014, and during the period, 85 species were identified in the fields surveys of winter season, were categorized as 63 residents, 18 winter visitors, 3 summer visitors and 1 transit- winter visitor and while 83 of them were in the category of LC (Least Concern), one was located in the category of NT (Near Threatened) and 1 has been identified as VU (Vulnerable). During field surveys of spring season, 88 species consisted of 59 residents, 25 summer visitors and 4 transits, were categorized as 84 LC, 1 NT, 2 VU and one EN (Endangered), while total 115 species comprised 69 residents, 41 summer visitors, 4 transits and 1 transit-winter visitor were categorized as $113 \mathrm{LC}, 1 \mathrm{VU}$ and $1 \mathrm{EN}$ during summer season. Including 68 resident, 6 winter visitors, 9 summer visitors, 2 transits, 2 transit-winter visitors and 1 resident -summer visitors, total 88 species were determined in the field surveys of the autumn season. Among them, 87 were located in the category of $L C$ and one was identified as $\mathrm{VU}$.

Interpretation : Kovada Lake National Park, Kızıldağ National Park, Gölcük Nature Park, Yazılı Canyon Nature Park, Başpınar Nature Park, Sığla Forest Nature Reserve Area in Kargı Village and Kasnak Meşesi Nature Reserve Area are located within the borders of Isparta. Destruction of natural habitats, due to agricultural practices and human activities occurring in those areas whereas other habitats, richness of bird species were affected. Eradication of these problems arising from human effect will be resolved with relevant conservation.
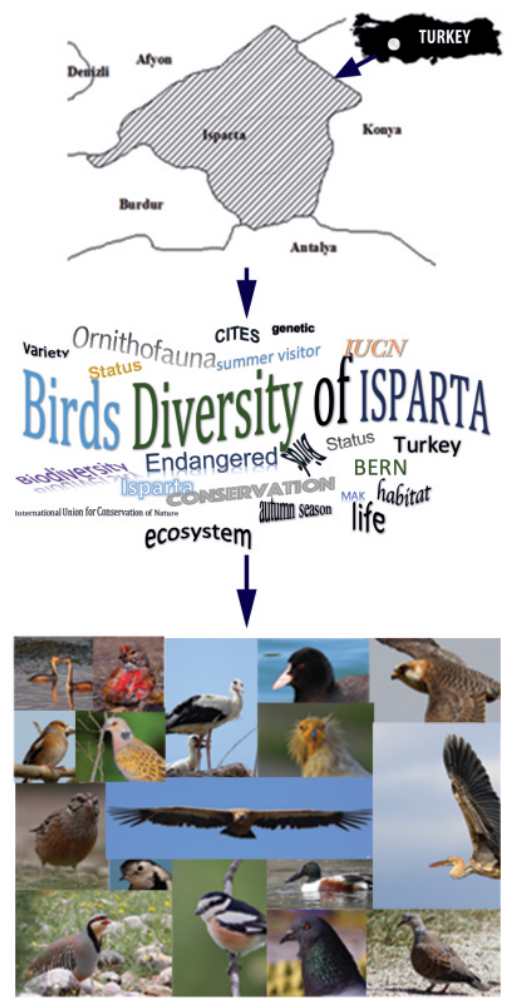


\section{Introduction}

Due to its characteristics of being the crossroads of three continents, Turkey has quite a lot species diversity. It is also a bridge and a junction point in terms of biodiversity (Atalay and Efe, 2015). During the glacial periods, it became a major point as a refuge area for many species. It is even in the position of the centre of gene bank for some kind of species (Demirsoy, 1999). Turkey is one of the rare countries with respect to natural life. Turkey is dominated by different types of climate, mountain chains including different rock structures, plateaus and plains (Atalay, 2008). Two of the four bird migration routes in the Palearctic region pass through Turkey. The first of these is the Northwest-South route, which passes first from Thrace to the Straits and then to Anatolia. The second is the northeast-south path, which originates in the Eastern Black Sea Region to pass through the Çoruh River and extends to Eastern Anatolia (Yiğit et al., 2008).

Depending upon its geographical position and habitat diversity, a total of 502 bird species including 437 regular and 65 random, have been observed in Turkey, which is located on the major migration routes (Kiziroğlu, 2008; Atalay and Efe, 2015).

Isparta province where the study was carried out is home to many birds with high mountains, wetlands, forests and other habitats. Also, it is one of the areas where migratory bird species can find suitable habitats during migration due to its geographical location.

\section{Materials and Methods}

Study area : Isparta Province is located in the Lakes Zone situated in the North of the Mediterranean Region and the Western Taurus Mountains Zone. The geographic coordinates of the province lie between $30^{\circ} 20^{\prime}-31^{\circ} 33^{\prime} \mathrm{E}$ and $37^{\circ} 18^{\prime}-38^{\circ} 30^{\prime} \mathrm{N}$. Having $8.933 \mathrm{~km}^{2}$ of total land area, Isparta is encompassed by Sultandağ, Çay, Suhut, Dinar and Dazkırı districts of Afyon province Province from north and northwest while it borders Ağlasun, Bucak and Centre districts of Burdur Province in the south and southwest. From east and southeast, it is surrounded by Akşehir, Doğanhisar and Beyşehir districts of Konya province (Fig.1).

The field surveys were carried out in the relevant habitats after the literature review (Fig.1). The areas, which were identified on the basis of suitability for the natural habitats of species, were selected to represent multiple habitats such as forest, high mountain, moorland, wetland, sand dune, farmland and settlement, etc. During the observations, species were determined through binoculars, telescope and SLR camera. The coordinates of the observation areas were specified with the help of Global Positioning System (GPS).

The species were determined by Line transect and Point counts method (Dobinson, 1976; Bibby and Burgess, 1992).
Besides direct sighting and identification, the observations were noted through some signs and traces belonging to birds such as footprints, faeces, voices, wing shapes and feathers. The observation methods applied were selected in accordance to the species.

\section{Results and Discussion}

In the present study, which was carried out in Isparta/Turkey between 2013 and 2014, a total of 266 bird species belonging to 53 families were reported (Table 1). These species include 128 residents, 75 summer visitors, 38 winter visitors and 25 passage migrant (Fig.2).

According to the International Union for Conservation of Nature (IUCN), six of the identified species were considered as vulnerable (VU), one of them as endangered (EN) and the number of near threating (NT) species were eight while 251 of them are under the low risk (LC) (Fig. 3, Table 1).

During the fields surveys performed during winter season, total 31723 individuals and 85 species were determined. Among them, Fulicaatra (Common coot) was placed on the top with 25293 (79.73\%) birds, while the species having the highest number of individuals were Phalacrocorax carbo (Great cormorant) 2057 (6.48\%), Aythya ferina (common pochard) 531 (1.67\%), Corvus cornix (Hooded crow) 447 (1.41\%), Passer domesticus (house sparrow) 337 (1.06\%), Ardea alba (Great white egret) $289(0.91 \%)$, Fringilla coelebs (Eurasian chaffinch) 285 (0.90\%), Ardea cinerea (grey heron) 232 (0.73\%) respectively.

During the spring field surveys, a total of 88 species and 2867 individuals were identified, Hirundo rustica and Delichon urbicum were determined as the species that had highest number of individuals with $21.24 \%$ and $15.77 \%$ respectively. In addition, Neophron percnopterus (Egyptian vulture) was among the endangered species with respect to IUCN status. The significance of the zone located on the northwest-south route was increased as the endangered or near threatened species were mostly observed in this circle comprising the area around Yalvaç and Şarkikaraağaç districts.

9088 birds and 115 species were identified over the course of the field surveys carried out during the summer season. Among these species having the highest number of individuals, Hirundo rustica (barn swallow) ranked first with 2071 individuals (22.79\%), while the others were Passer domesticus (house sparrow) 929 (10.22\%), Apus apus (common swift) 868 (9.55\%) and $453(4.98 \%)$ Sturnus vulgaris (common starling), respectively.

During the field surveys of autumn season, 16442 individuals and 88 species were determined. With a number of $9321(56.69 \%)$ individuals, the first place among the species 


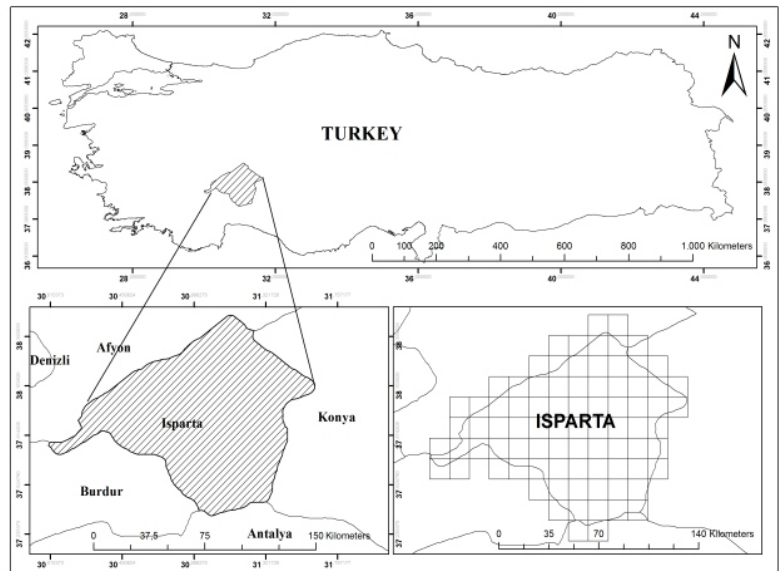

Fig. 1 : Location of study area

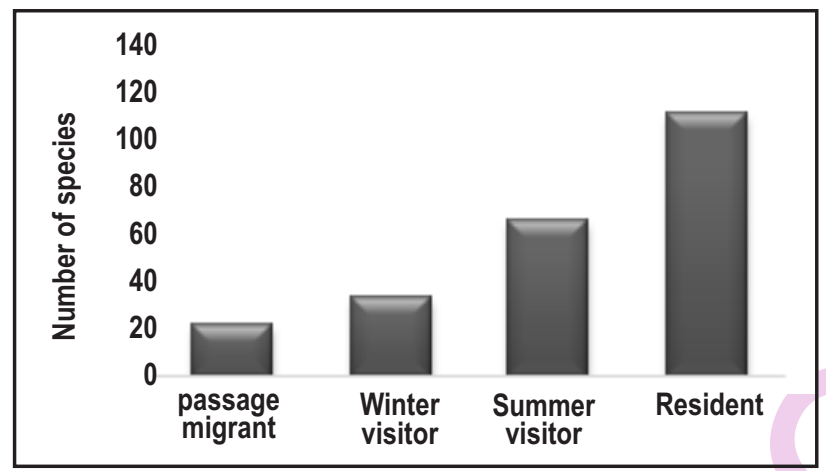

Fig. 2 : Movement patterns of birds in Isparta

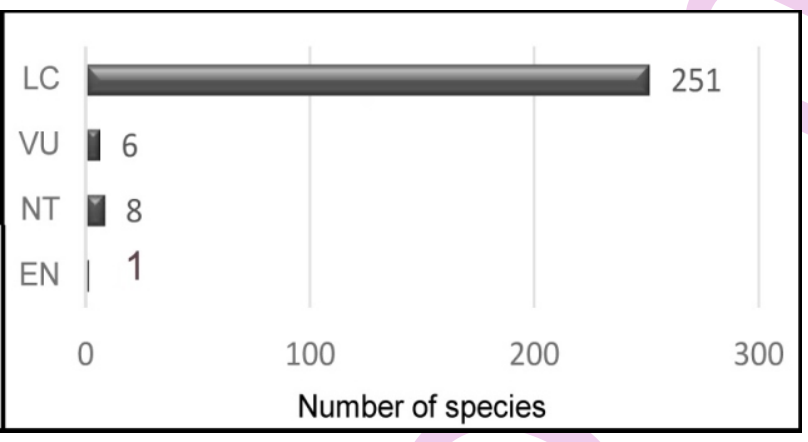

Fig. 3 : Status of birds in Isparta

having the highest number of individuals has been taken by Fulica atra (Common coot), which is followed by Phalacrocorax carbo (Great Cormorant) and Sturnus vulgaris (common starling) with $2068(12.58 \%)$ and $905(5.50 \%)$ individuals respectively. In the same period, Gypaetus barbatus (bearded vulture) has been identified as NT (near threatened species) and the areas, where this species was observed, has great importance for monitoring both the species and the field. When the distance from their nests situated in the Köprülü Canyon National Park located in the
Antalya province, ware taken into consideration, preservation of this vulture species was found as inevitable.

Several ornithological studies were carried out in various times in Isparta province (Tabur, 2002; Gündoğdu, 2002; Tabur and Ayvaz, 2005; Tabur and Ayvaz, 2006a,b; Şimşekli et al., 2011; Öztürk and Tabur, 2010; Öztürk and Tabur, 2013; Soylu and Tabur, 2015). However, these studies remained restricted in local areas and species studies. With this study, seasonal distribution of species was revealed through a broader determination of species and habitat.

Turkey is in the key position for many bird species. A wide range of bird species live in various ecosystems of Turkey. To maintain this richness, it is essential to understand the dimensions of diversity and to determine and take measures against substantial threats. In this context, several precautions at international and national level have been taken for the conservation of biological diversity and this is being done in the interest of large biodiversity of birds.

Birds are ideal bio-indicators (Rajashekara and Venkatesha, 2015). They are sensitive even to small environmental changes. For this reason, they are considered as a healthy indicator for the productivity of ecosystem and ecological conditions (Newton, 1995; Desai and Shanbhag, 2007; Li and Mundkur, 2007). It was identified from the literature that Tota mountain and the surrounding area, which is also one of the fields of this study was previously used as nesting site by five griffon vultures. Therefore, it has great importance to protect this species as the number of individuals and habitats are decreasing every passing day, even though they reproduce once a year. Through statistical analysis, it was found that the cause for this species to abandon Yazilı Canyon was the negative effects of marble quarries, which destroyed their breeding areas Öztürk and Tabur (2013). This was also the primary reason for individuals to settle into Tota Mountain and its surroundings. Thus, this habitat, which is far from threatening factors, is preferred by this species as a new breeding and perching place.

Comprising a part of the research area of this study, The northwest-south route passing from Thrace to the Straits and then to Anatolia has great importance. In addition, Isparta provides birds with the opportunity of relaxation, breeding and accommodation during both the migratory season and the rest of the period in a year thanks to its wetland areas. Habitat conservation of water bodies is most important for sustaining the population of migratory and other wetland birds (Arya et al., 2014). Protection of species also means the conservation of the resources for ecotourism. Ross and Wall (1999) argue that appropriate management can provide balance between conservation and development by establishing a strong link between local residents and tourism. For this reason, problems arising from mining, which has been identified as a potential 


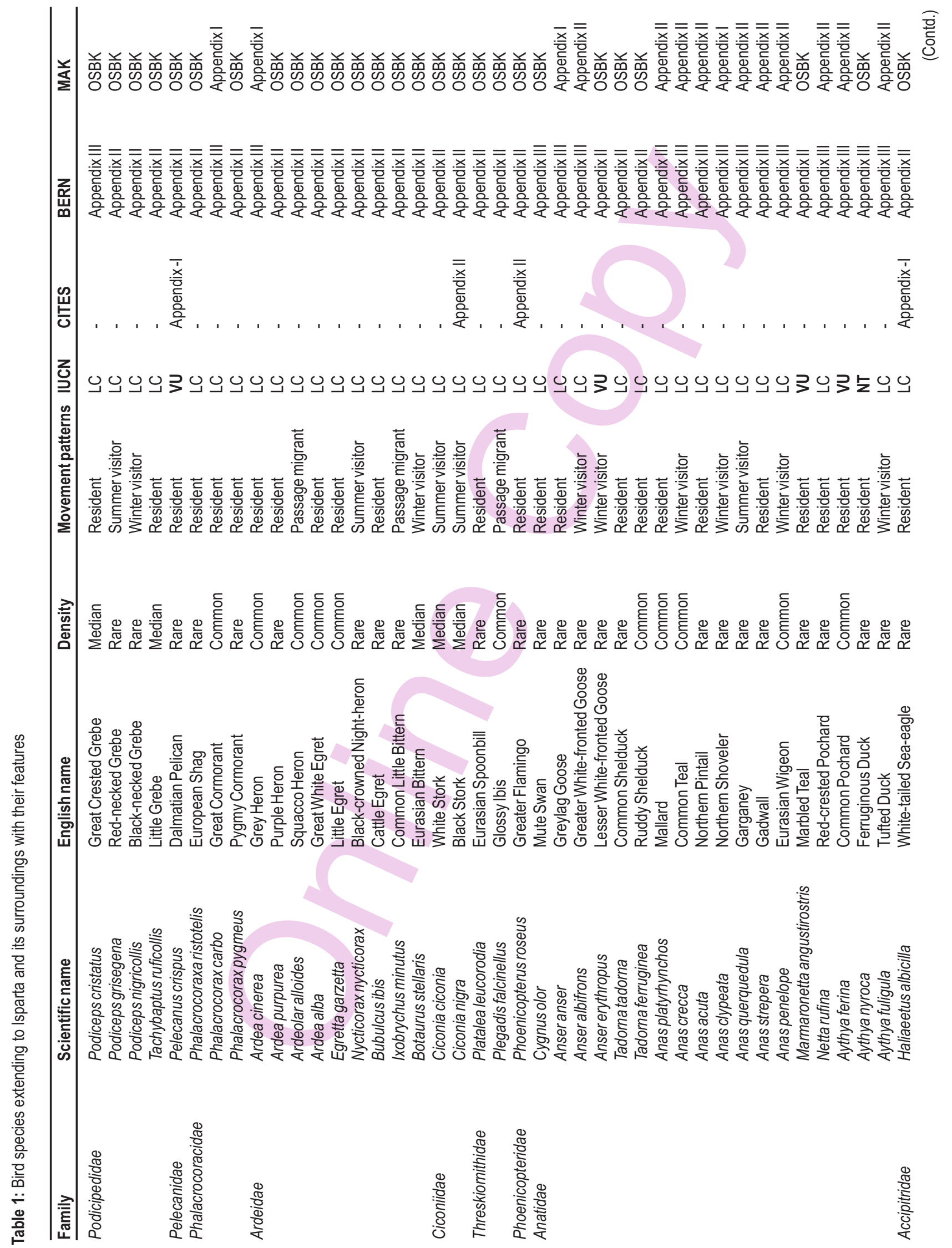




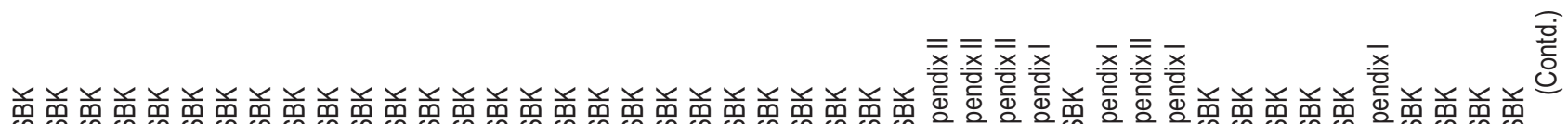

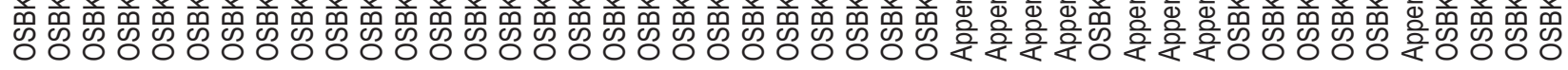

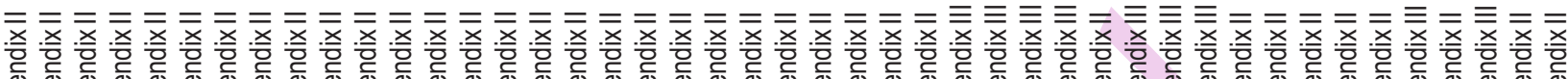

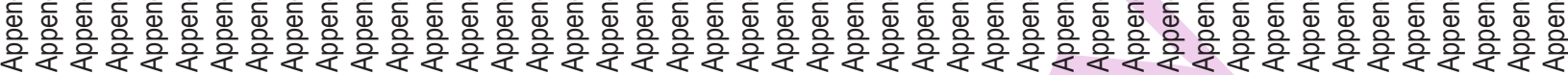

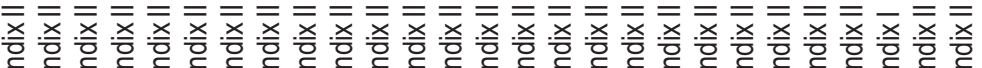

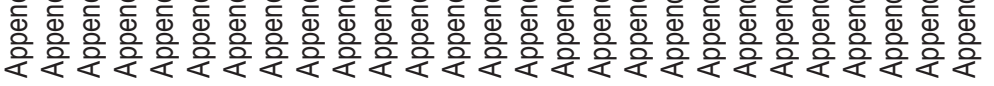

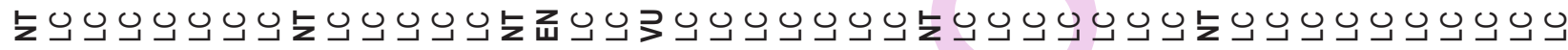

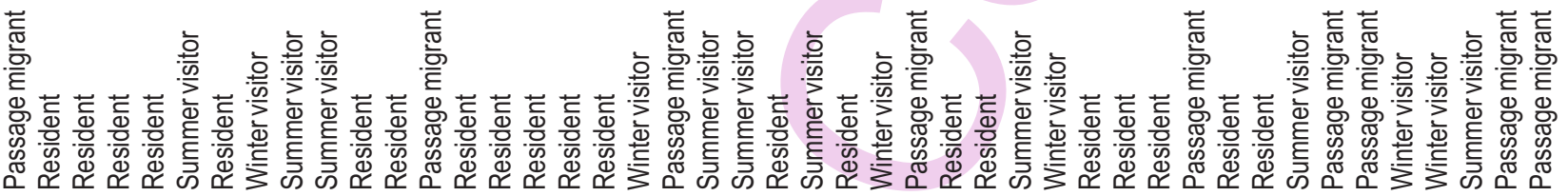

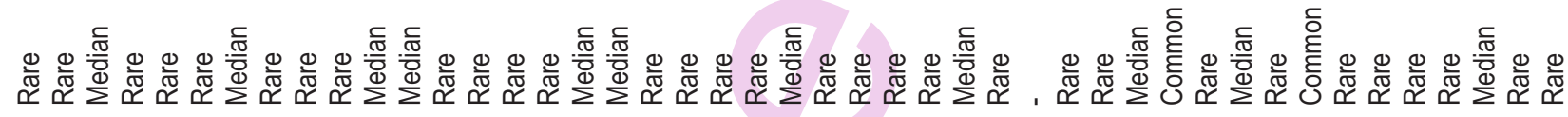

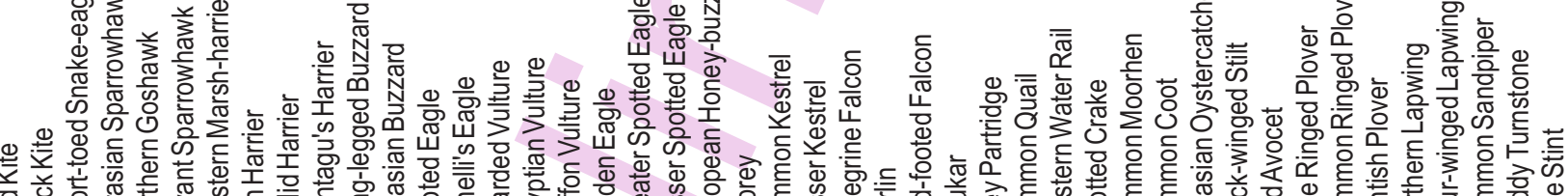

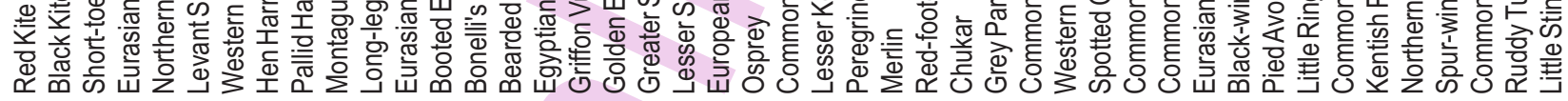

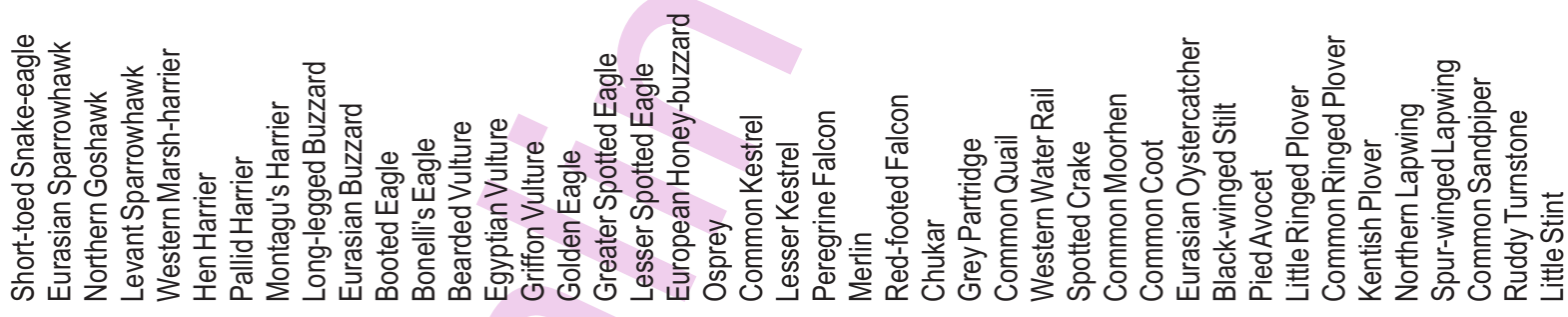

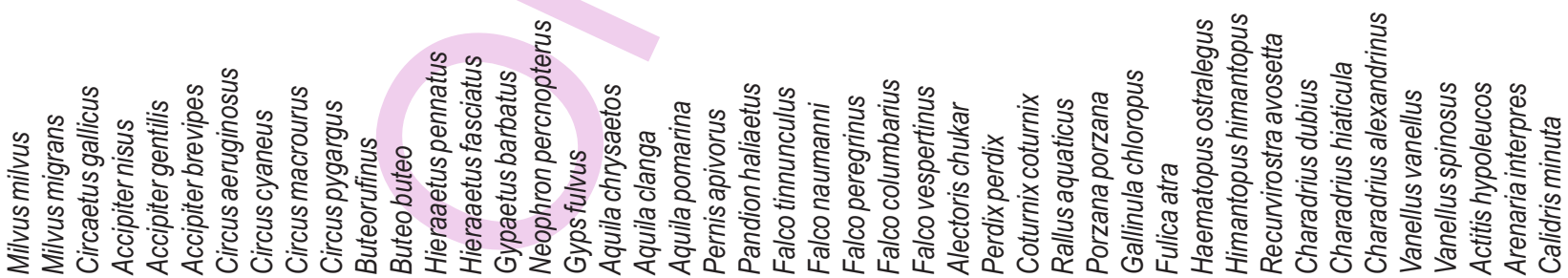

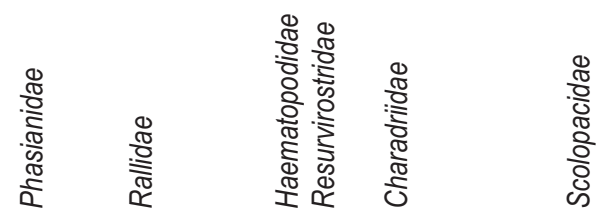




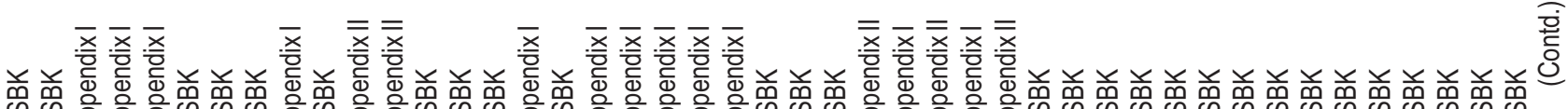

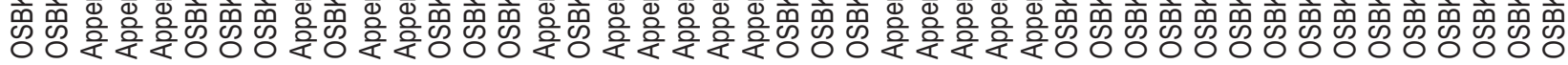

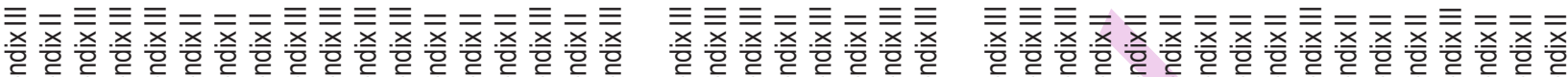

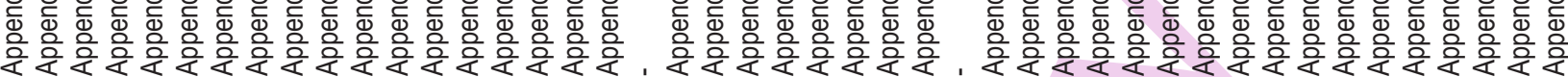

UO

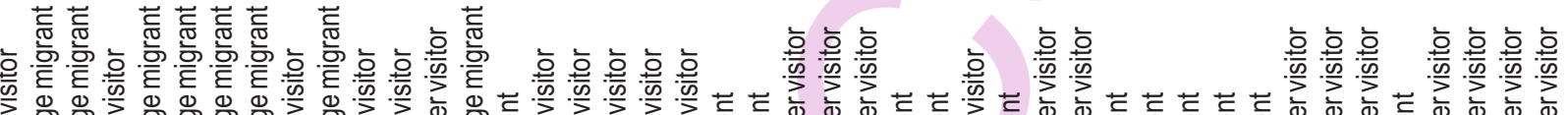

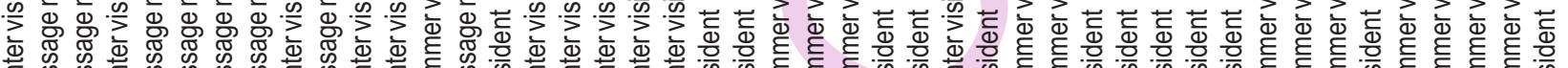

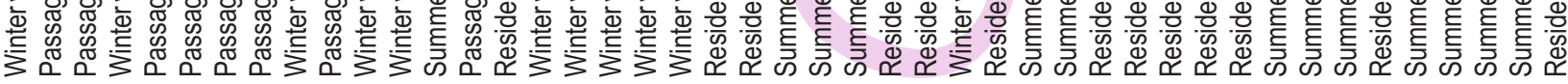

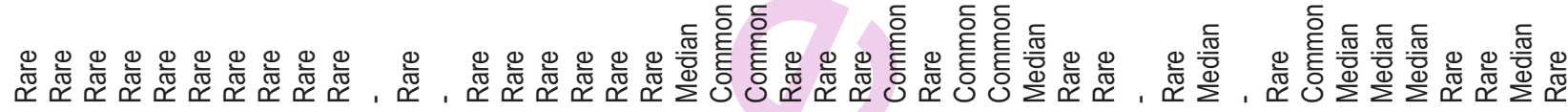

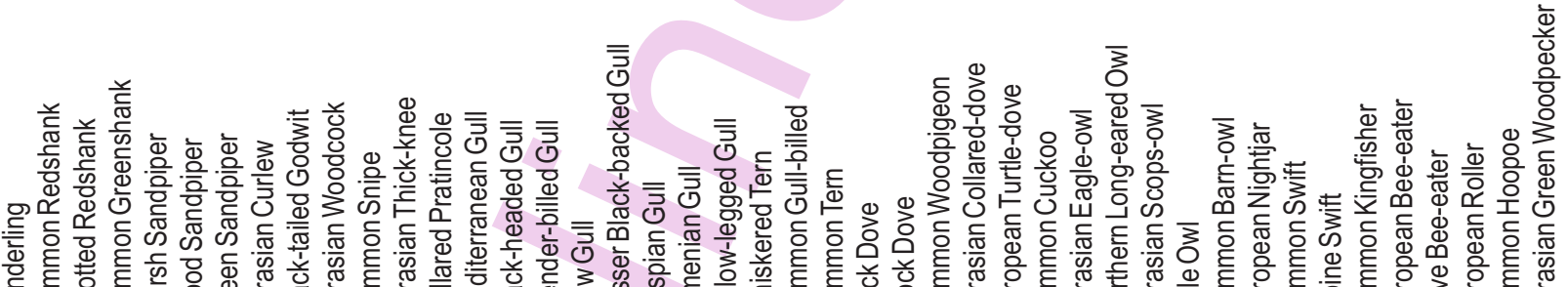

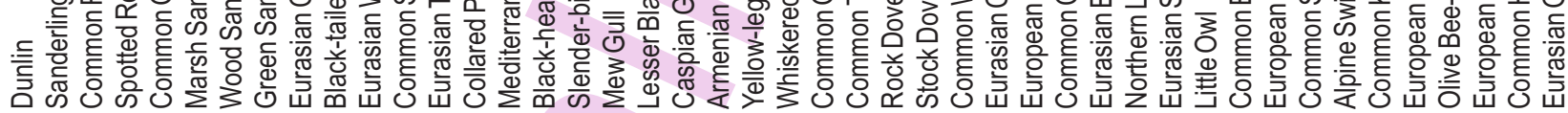

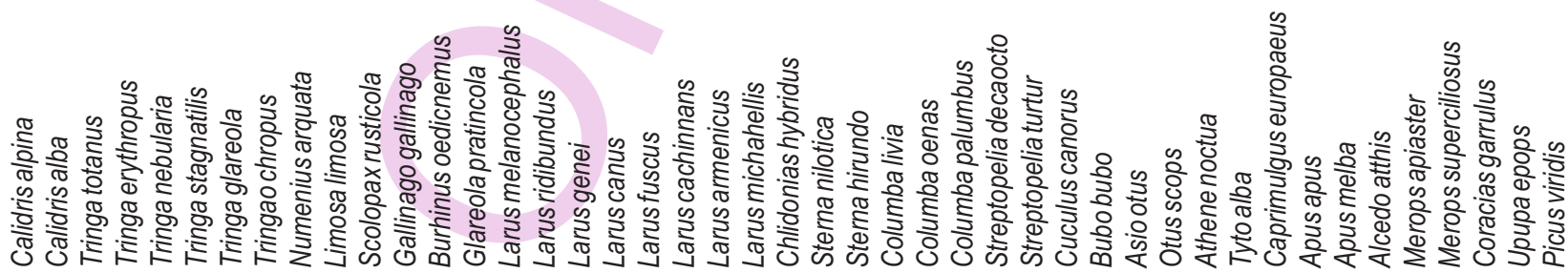

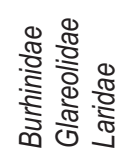

$\frac{\pi}{\pi}$
$\frac{0}{2}$
है
응

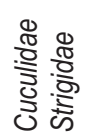

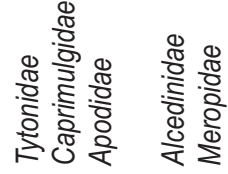

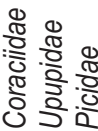




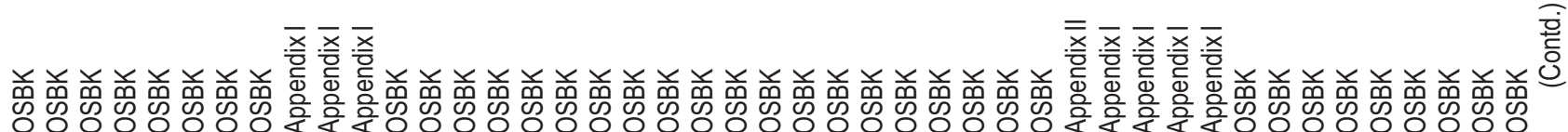

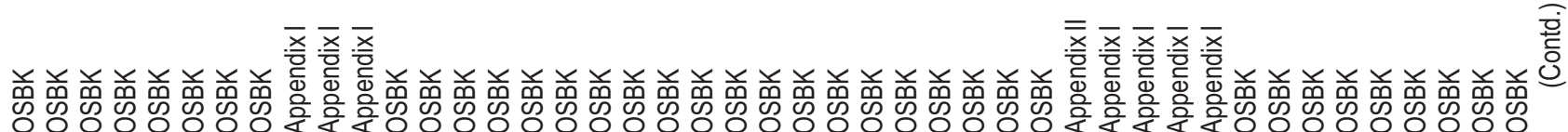
8.838

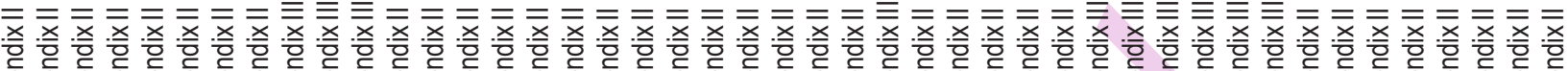

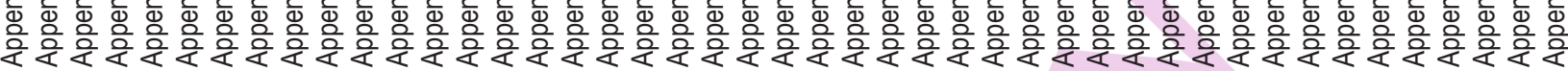

勾

毫旁

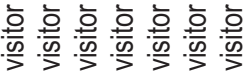

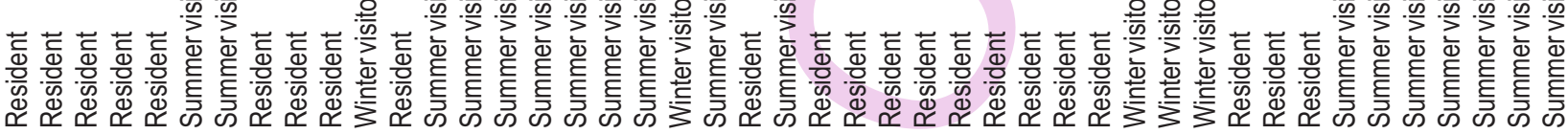

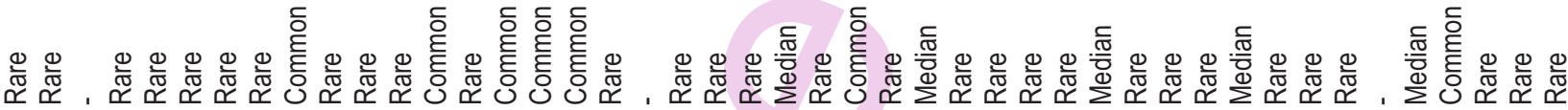

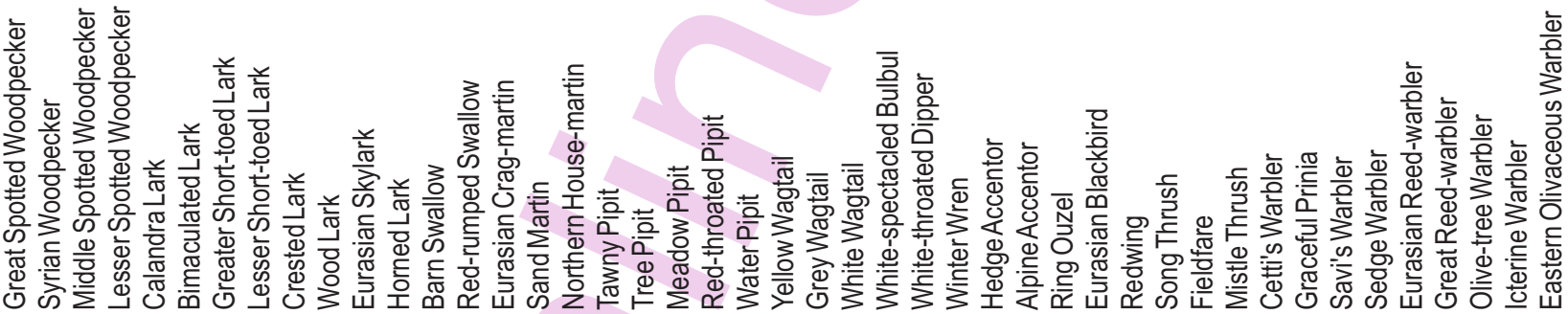

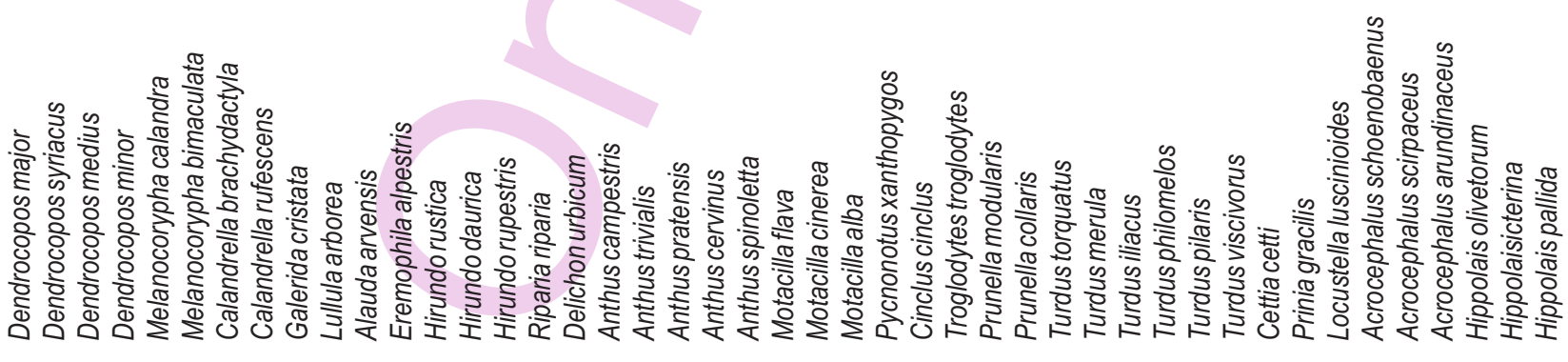

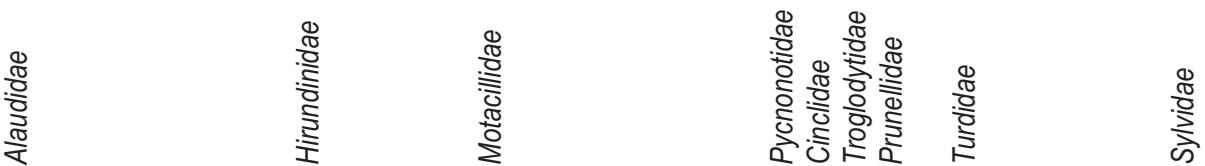




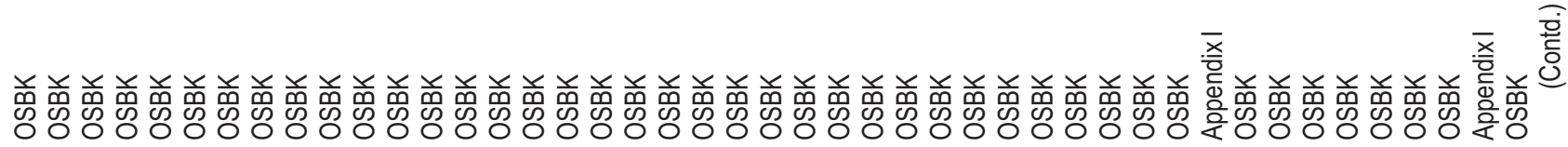

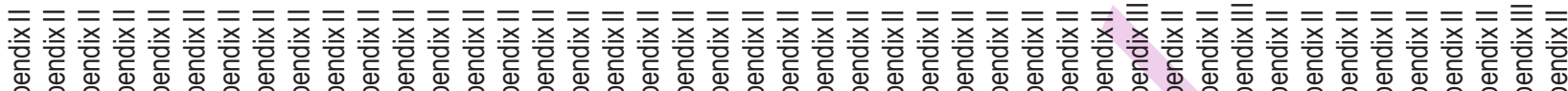

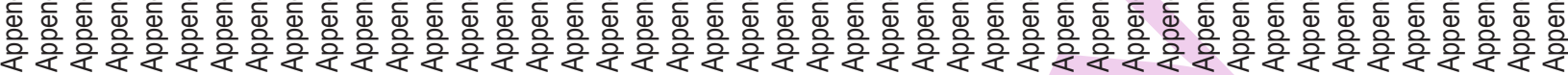

ب0

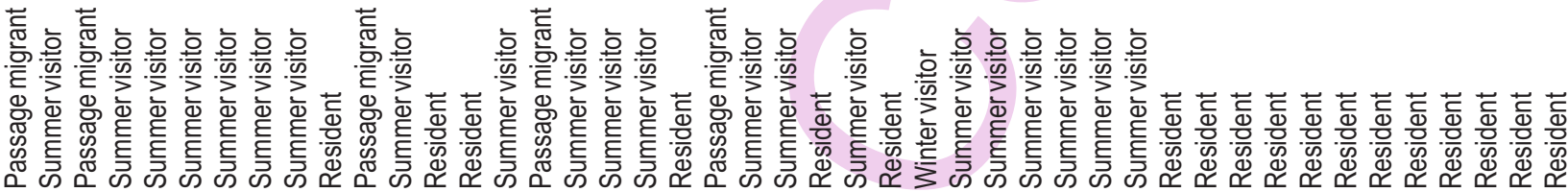

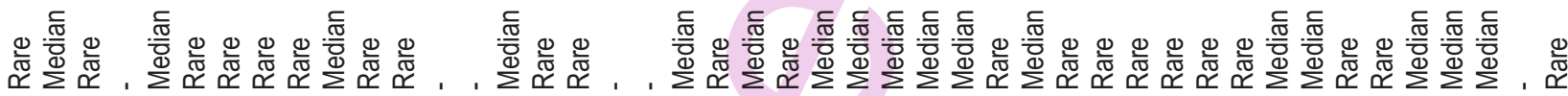

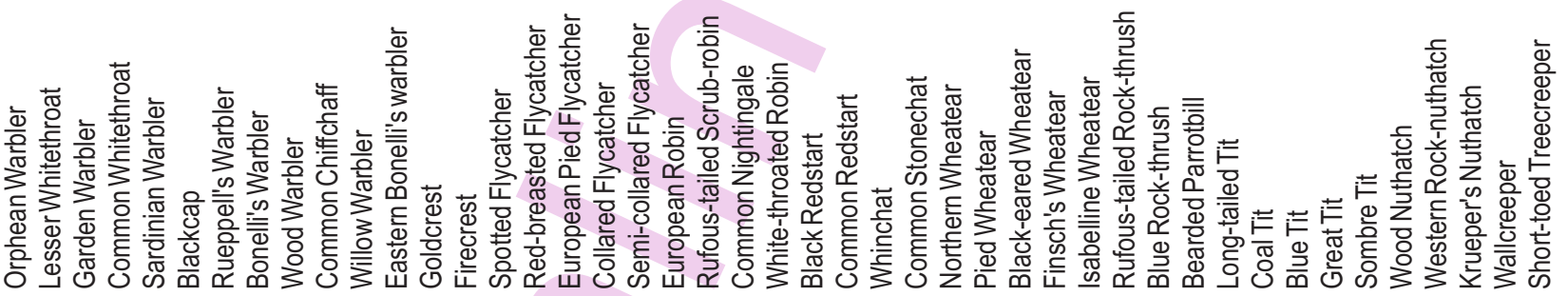

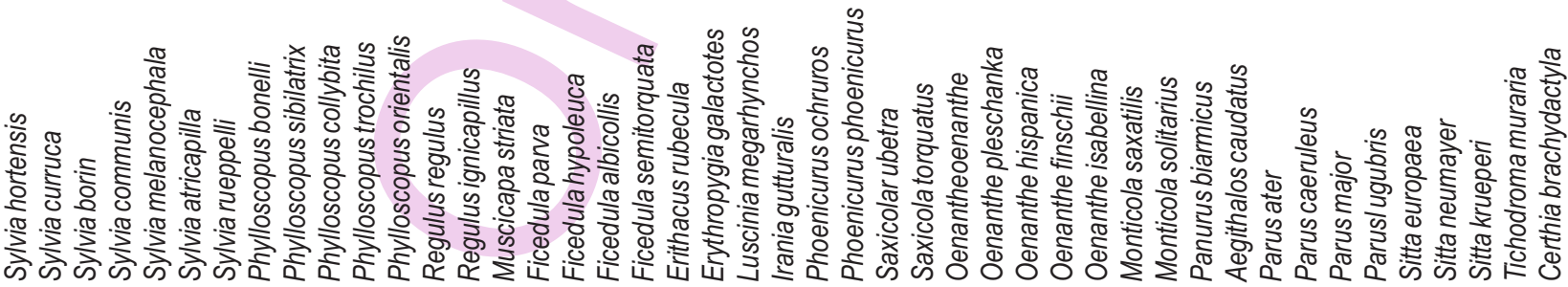

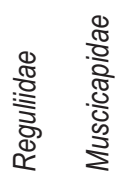

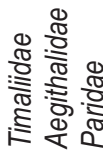<smiles>[Hg][Hg]</smiles> 


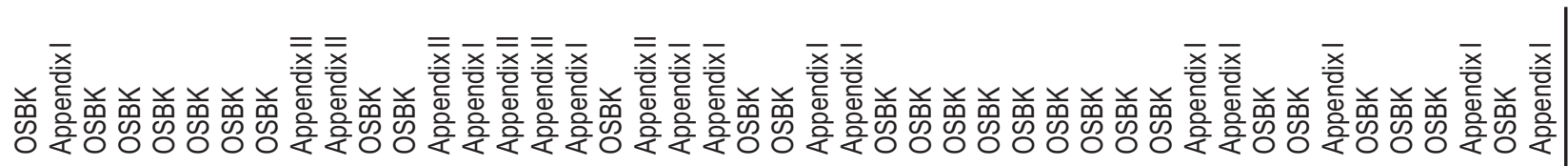

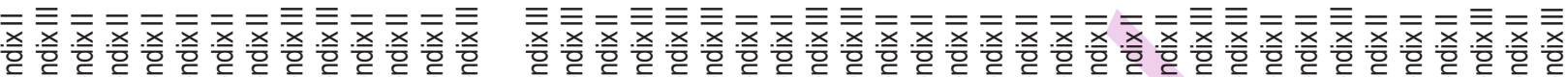

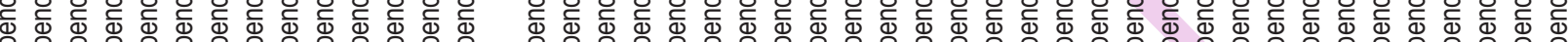

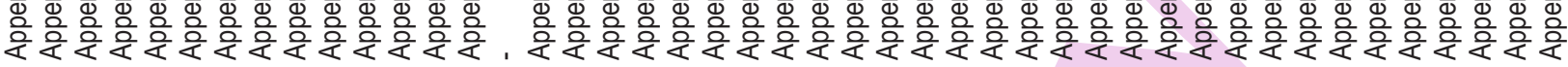

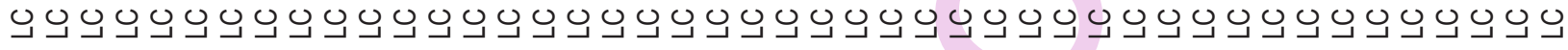

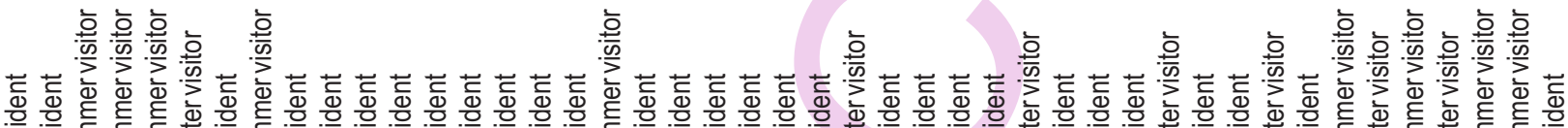

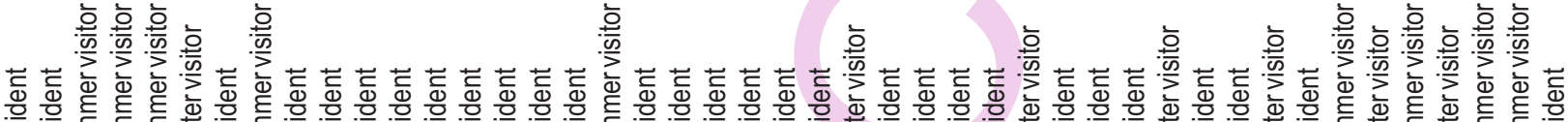

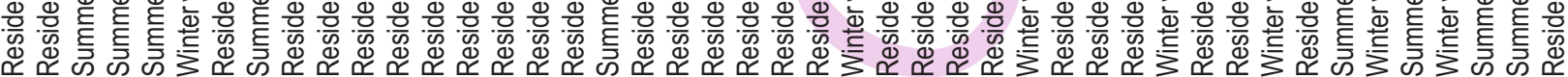

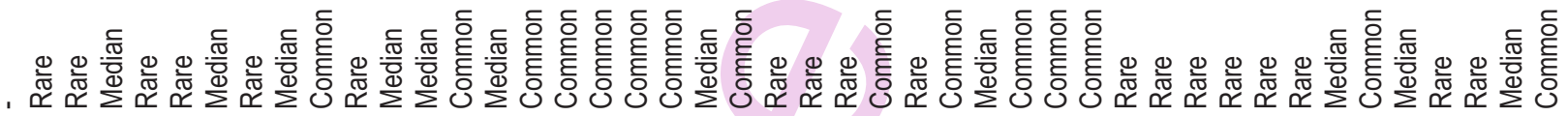

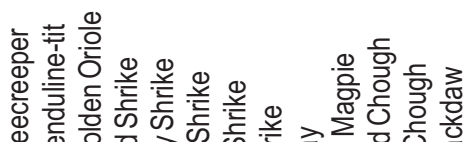

\begin{tabular}{lll} 
& \\
\hline
\end{tabular}

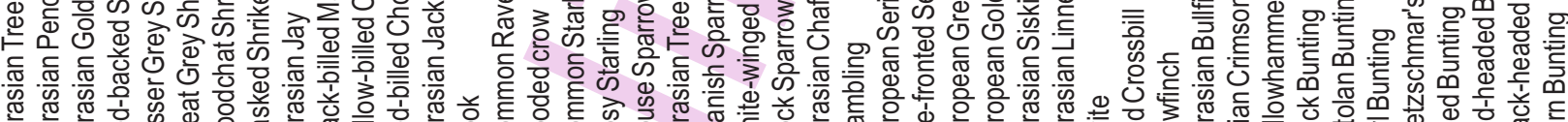

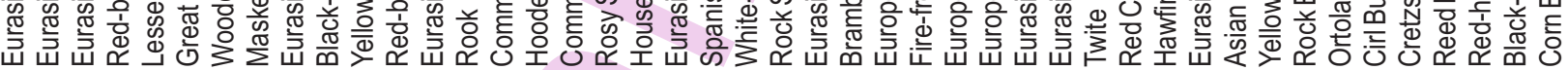

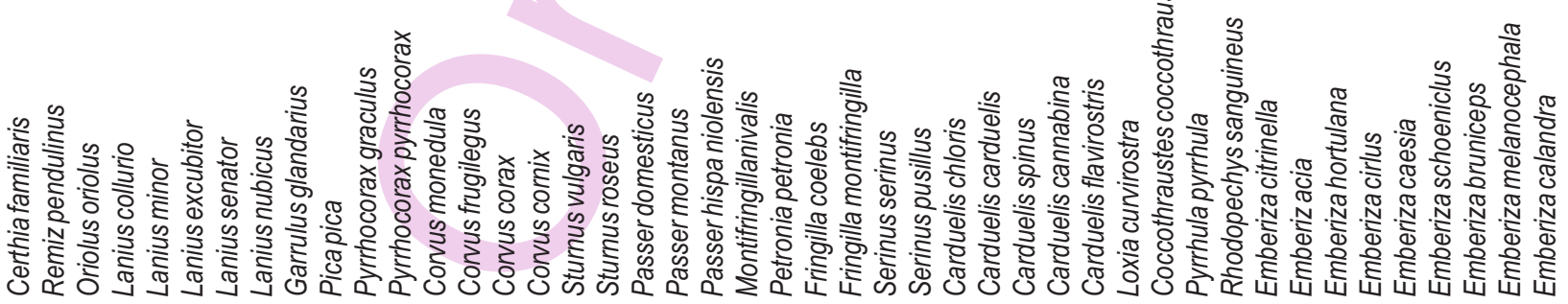

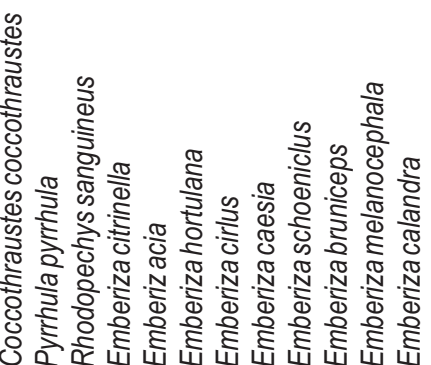

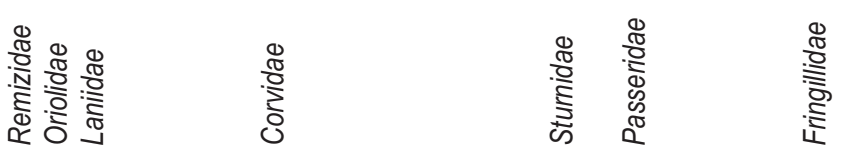

$\frac{8}{8}$
.
है
है

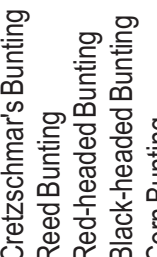

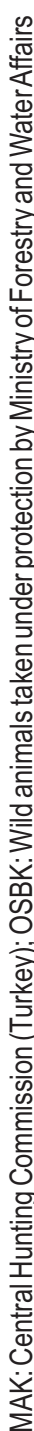


threat and later ecosystem changes, agricultural practices and human activities can be resolved with relevant conservation.

\section{Acknowledgments}

The author thanks T.C. Ministry of Forestry and Water Affairs, VI.District Directorate of Nature Conservation and National Parks,Ekoiz Environmental and Social Planning Research Training and Consulting Trade. Ltd. Sti.I am indebted to PhD student Biologist Ibrahim TAVUÇ.

\section{References}

Arya, M., R.J. Rao and A.K. Mishra: Avifaunal occurrence and distribution of wetland birds in Sakhya Sagar and Madhav Lakes in Madhav National Park, Shivpuri, India. J. Environ. Biol., 35, 703-708 (2014).

Atalay, I..:Ecosystem Ecology and Geography (Ekosistem Ekolojisi ve Coğrafyası). Meta press, İzmir, p. 824 (2008).

Atalay, I. and R. Efe: Biogeography of Turkey (Türkiye Biyocoğrafyası). Meta Press, Izmir, Turkey (2015).

Bibby, C.J. and N.D. Burgess: Bird Census Techniques. Academic Press Limited, London. p. 257 (1992).

Bird Life International: Birds in the European Union: a status assessment. Wageningen, the Netherlands: BirdLife International. p. 50 (2004).

Demirsoy, A.: Invertebrates-Invertebrates outside of insects (Basic Rules of Life). 2, p. 1210,Ankara (1999).

Desai $M$. and $A$. Shanbhag: Birds breeding in unmanaged monoculture plantations in Goa, India. Indian Forester., 133, 1367-1372 (2007).

Dobinson, H. M.: Bird Count, A Practical Guide to Bird Survey. Keztrel Books, Published by Penguin Books Ltd. Hormondsworth, Middlesex, England, p.192 (1976).

Gündoğdu, E.: Observations on forest birds in some protected areas around Isparta. Suleyman Demirel University. Turkish J. Fores., 1, 83-100 (2002).

International Union for Conservation of Nature (IUCN): The IUCN Red List of Threatened Species. Version 20154 (www.iucnredlist.org) (2016).
Kiziroğlu, I.: Red Data Book for Birds of Turkey. Desen Press, Ankara, p. $148(2008)$

Li Z, W. D. and T. Mundkur: Numbers and distribution of waterbirds and wetlands in the Asia-Pacific region. Results of the Asian Water bird Census: 2002-2004. Wetlands International, Kuala Lumpur, Malaysia (2007).

Newton, I.: The contribution of some recent research on birds to ecological understanding. J. Animal Ecol., 64, 675-696 (1995).

Öztürk, Y. and M.A.Tabur: Seasonal and daily activity pattern in griffon vulture in Sütçüler (Isparta-Turkey). Biotechno Biotechnol., EQ. 24/2010/SE Special Edition/On-Line, 667-670 (2010).

Öztürk, Y. and M.A. Tabur:A species in an ever shrinking habitat in Isparta and Antalya: Griffon vulture (Gyps fulvus).Suleyman Demirel University. J. Natural App. Sci., 17, 18-25 (2013).

Rajashekara, S. and M.G. Venkatesha: Temporal and spatial avian community compositon in urban landscapes of the Bengaluru region, India. J. Environ. Biol., 36, 607-616 (2015).

Ross, S. and G. Wall: Ecotourism: Towards congruence between theory and practice. Tourism Management, 20, 123-132 (1999).

Soylu, A. and M.A.Tabur: Breeding biology of Fulica atra L. 1758 population in Kovada Lake (Isparta). Suleyman Demirel University. J. Natural App. Sci., 19,111-114 (2015).

Şimşekli, M., M.A., Tabur and M. Kara: The Birds of Kızıldağ National Park (Isparta). Nature and Man, 32-42 (2011).

Tabur, M.A.: Bioecology of lakes region birds (Göller Bölgesi, Gölhisar Lake, Burdur Lake, Eğirdir Lake, Kovada Lake, Beyşehir Lake).Suleyman Demirel University.Graduate school of natural and applied sciences, PhD Thesis, p.99, (2002).

Tabur, M. and Y. Ayvaz: The ornitofaunistic importance of Kovada Lake.Protected Natural Area Symposium-Oral Presentation Book, Isparta (2005).

Tabur, M.A. and Y. Ayvaz: Birds of Gölcük Lake (Isparta). Suleyman Demirel Universitiy, Graduate School of Natural and Applied Sciences, 10-1, 16-20 (2006)

Tabur, M. and Y. Ayvaz: Ornithofauna of Eğirdir Lake (Türkiye). Bull. Pure Appli. Sci., 25 A, 75-84 (2006).

Yiğit, N., F. Saygıll, E. Çolak, M. Sözen and A. Karataş: Ornitology "Bird Science" Lecture Notes. Umit Ofset press, Ankara, p. 371 (2008). 